\title{
AN ANALYTICAL FRAMEWORK ON SERVICE PERCEPTION IN INDIAN AIRLINES BEFORE AND AFTER CORPORATE RESTRUCTURING
}

\section{DIPA MITRA}

Head, M. Phil \& Ph.D. Department, Indian Institute of Social Welfare and Business Management, Kolkata, India \begin{abstract}
The present study aims to identify the major problem areas related to the passenger service quality in Indian Airlines, before and after the corporate restructuring undertaken. For this purpose, descriptive research design was developed with personal interviews and close ended questionnaire (for passengers), on the basis of 22 parameters of passenger service quality. For this study, data were collected from the passengers travelling to and from Kolkata, Delhi, Mumbai, Chennai and Bangalore airport. After collecting data from 306 respondents through questionnaire survey, Factor analysis and Chi-Square Test had been used with the help of SPSS software and Statistics Calculator, to analyze the data and to identify the most fragile areas related to passengers service quality in pre and post restructuring.

This study reveals that this state owned public organization is still suffering from the technical problems like Availability of flight i.e. punctuality of the flights and easy availability of tickets, followed by some human factors such as Luggage Handling, Staff Assistance, Responsiveness and Assurance.

A Bayesian probabilistic framework has been developed from the dataset, which corroborates the findings of factor analysis. Scenario and causal analysis of the Bayeasian Framework suggests policy interventions and measures, so that this age old airlines can regain its previous status.

KEYWORDS: Luggage Handling, Staff Assistance, Responsiveness \& Assurance
\end{abstract}

Received: Jul 14, 2017; Accepted: Aug 04, 2017; Published: Aug 21, 2017; Paper Id.: IJBMRAUG20178

\section{INTRODUCTION}

Evolving economic scenario and consequent changes in ground reality and reforms have compelled reshaping Indian aviation industry. Years back, after liberalization, entry of private operators and the high cost of fuel led to a number of mergers in Indian aviation, including a high-profile agreement to combine Indian Airlines with Air India. But, the turbulence is likely to continue, as new carriers enter the fray to fill the gaps left by consolidation.

The industry had a cherished past in India, beginning early in the second half of $20^{\text {th }}$ century, when a crowd of private airlines attempted entry and competed for increased market share. Chaos reigned in the absence of workable regulations, and in 1953, a few years after independence; the airlines were nationalized and merged to set up two flag carriers i.e. Air India for international operations, and Indian Airlines for the domestic sector. It was one of the two flag carriers of India, the other being Air India. The airline officially merged into Air India on 27 February 2011, operating with a fleet of over 130 aircraft.

The present study aims to identify the major problem areas related to the passenger service quality in Indian Airlines, before and after the corporate restructuring; to cross- check the impact of the merger on those particular areas, second round interview from different customer segments has been conducted; and to develop an 
management framework to facilitate policy implementation regarding enhancement of passenger service of Indian airlines.

\section{LITERATURE REVIEW}

According to the conventional professional wisdom, restructuring is defined as any major reconfiguration of internal administrative structure that is associated with an intentional management change program (e.g. McKinley and Scherer 2000).

Restructuring is commonly referred to as downsizing, which may boost organizational efficiency and effectiveness (e.g. Smallwood and Jackson, 1987; Bailey and Szerdy, 1988; Freeman and Cameron, 1993; Bartol, Martin, Tein, and Matthews, 2001). It is suggested that the environment shift, technology changes, organizational growth and leadership changes are the reasons that lead to restructuring (e.g. Miller and Friesen 1984, cited in Bolman and Deal, 1997, p.73). There is also a perception that the adoption of advanced manufacturing technology and new human-resource management practices favor organizational change (e.g. Massimo and Delmastro 2002).

According to previous research studies, $70-80 \%$ of acquisitions fail, meaning that they create no wealth for the share owners of the acquiring company (e.g. Selden and Colvin 2003).

As it is usually referred to, 21 st century is considered as the century of service industry. Service industry is growing at a rapid pace across developed and developing countries, and present research, as such, is based on the service quality of Indian airlines. The objective of this study is to find out whether the corporate restructuring of Indian airlines has brought any improvement in their passenger service.

\section{METHODOLOGY}

This study adopted descriptive research design to portray the service perception of airline customers. Primary data were collected with the help of personal interview and close ended questionnaire (for the passengers), on the basis of 22 passenger service quality parameters i.e. ease of ticketing, punctuality, arrival and departure assistance, handling delays/ cancellations, luggage handling, seat comfort, cleanliness, catering service, overall safety, customer complaint handling and attitude and behavior of the staff.

For this study, data were collected from the passengers travelling to and from Kolkata, Delhi, Mumbai, Chennai and Bangalore airport. After collecting data from 306 respondents through questionnaire survey, reliability analysis was performed. Factor analysis was used with the help of SPSS software to analyze the data and to identify the most fragile areas related to passenger's service of Indian airlines in pre and post restructuring phase. Henceforth, to cross check the impact of the merger, second round interview from different customer segments was taken up to analyze their views regarding passenger service quality in the Indian airlines, after its corporate restructuring. For this purpose, Chi- Square Test was done with the help of Statistics Calculator.

\section{DATA ANALYSIS}

Before Merger

Table 1: Reliability Statistics

\begin{tabular}{|c|c|}
\hline Cronbatch's Alpha & N of Items \\
\hline .863 & 22 \\
\hline
\end{tabular}

Firstly, reliability analysis was performed on the data set. Here, the value of Cronbach's Alpha.863 is acceptable, as it confirms that there is internal consistency of the set of items of a given scale. 


\section{FACTOR ANALYSIS}

Here, Barlett's test of spericity is significant, as p value is. 000 which is less than. 05 . Thus, from the perspective of Bartlett's test, factor analysis is feasible. As Bartlett's test is significant, a more discriminating index of factor analyzability is the KMO. High values (between 0.5 and 1.0) indicate factor analysis is appropriate. Values below 0.5 imply that factor analysis may not be appropriate. For this data set, it is.874 (very close to 1.0), which is very large, so the KMO also supports factor analysis.

\section{FACTOR IDENTIFICATION}

\section{Determination Based on Eigen values}

In this approach, only those factors with eigenvalues greater than 1 are considered. Other factors are not included in this model.

Here, from the SCREE PLOT and the table TOTAL VARIANCE EXPLAINED, 5 factors are identified; whose eigenvalues are more than 1 .

\section{Determination Based on Percentage of Variance}

The number of factors extracted can also be determined in a way, so that the cumulative percentage of variance extracted by the factors reaches a satisfactory level.

Here, according to the analysis, the cumulative percentage of variance extracted by the 5 factors is $66.127 \%$ ( from the table TOTAL VARIANCE EXPLAINED), which is quite satisfactory.

\section{Factor Interpretation}

Factor interpretation is facilitated by identifying the variables that have large loading on the same factor. That factor can be interpreted in terms of variables that load high on it.

In the ROTATED COMPONENT MATRIX,

Component 1: Has high coefficients. 770 and.669 for variables Catering Service and Overall Safety

Component 2: Has high coefficient.833 for variable Arrival \& Departure Assistance

Component 3: Has high coefficients.673 and.840 for variables Customer Complaint Handling and Attitude and Behavior of the Staff

Component 4: Has high coefficient.773 for variable Punctuality

Component 5: Has high coefficient.914 for variable Luggage Handling

Component 1: Is labeled as Reliability

Component 2: Is labeled as Staff Assistance

Component 3: Is labeled as Responsiveness

Component 4: Is labeled as Punctuality

Component 5: Is labeled as Luggage Handling

As Component 1 is treated as principal component, so, in this case, Reliability should be the most important factor 
or it can be termed as the major problem areas of Indian Railways at present, followed by the Staff Assistance, Responsiveness, Punctuality and Luggage Handling according to the passengers.

\section{After Merger}

Table 2: Reliability Statistics

\begin{tabular}{|c|c|}
\hline Cronbatch's Alpha & N of Items \\
\hline .805 & 22 \\
\hline
\end{tabular}

Reliability analysis has been performed on the data set. Here the value of Cronbach's Alpha.805 is acceptable, as it confirms that there is internal consistency of the set of items of a given scale.

Factor Analysis

Here, Barlett's test of spericity is significant, as p value is.000, which is less than.05; and thus, factor analysis is feasible. As Bartlett's test is significant, a more discriminating index of factor analyzability is the KMO. For this data set, the value of KMO is very high i.e. 824 (very close to 1.0), which is very large, so the KMO also supports factor analysis.

\section{Factor Identification}

\section{Determination Based on Eigen values:}

In this approach, only those factors with eigenvalues greater than 1 are considered. Other factors are not included in this model.

Here, from the SCREE PLOT and the table TOTAL VARIANCE EXPLAINED, 6 factors can be identified; whose eigenvalues are more than 1.

\section{Determination Based on Percentage of Variance}

The number of factors extracted can also be determined in a way, so that the cumulative percentage of variance extracted by the factors reaches a satisfactory level.

Here, according to the analysis, the cumulative percentage of variance extracted by the 6 factors is $69.101 \%$ ( from the table TOTAL VARIANCE EXPLAINED), which is quite satisfactory.

\section{Factor Interpretation}

Factor interpretation is facilitated by identifying the variables that have large loading on the same factor. That factor can be interpreted in terms of variables that load high on it.

In the COMPONENT MATRIX,

Factor 1: Has high coefficients.865 and.806 for variables Ease of Ticketing and Punctuality

Factor 2: Has high coefficients.816 for variables Luggage Handling

Factor 3: Has high coefficients. 789 for variables Behavior of the Staff

Factor 4: Has high coefficients.715 and.682 for variables Handling Delays and Cancellation \& Customer Complaint Handling

Factor 5: Has high coefficients.832 for variables Seat Comfort \& Safety

Factor 6: Has high coefficients.782 for variables Cleanliness 
Factor 1: Can be labeled as Availability

Factor 2: Can be labeled as Luggage Handling

Factor 3: Can be labeled as Staff Assistance

Factor 4: Can be labeled as Responsiveness

Factor 5: Can be labeled as Assurance

Factor 6: Can be labeled as Cleanliness

As factor 1 is treated as principal component, so, in this case, Availability should be the most important factor or it can be termed as the major problem areas of public airlines at present followed by the Luggage Handling, Staff Assistance, Responsiveness, Assurance and Cleanliness according to the passengers.

\section{CHI-SQUARE TEST}

H1: THERE IS NO DIFFERENCE OF OPINION BETWEEN THE CATEGORY OF RESPONDENTS (MALE OR FEMALE PASSENGERS) REGARDING THE STATEMENT THAT EVEN AFTER ITS CORPORATE RESTRUCTURING THE PASSENGER SERVICE QUALITY IN IA IS STILL NOT SATISFACTORY AS COMPARED TO PRIVATE AIRLINES OPERATING IN INDIA

Table 3

\begin{tabular}{|l|c|c|c|}
\hline TYPE OF RESPONDENT & TOTAL NUMBER & YES & NO \\
\hline Male Passengers & 52 & 40 & 12 \\
\hline female Passengers & 54 & 47 & 7 \\
\hline
\end{tabular}

Using STASTICAL CALCULATOR, it is found that

$$
\begin{array}{lc}
\text { Chi-square statistic } & =1.842 \\
\text { Degree of freedom } & =1 \\
\text { Probability of chance (p-value) } & =0.1747 \\
\text { Here p-value }>\alpha & (\alpha=0.05)
\end{array}
$$

Therefore, we accept the hypothesis

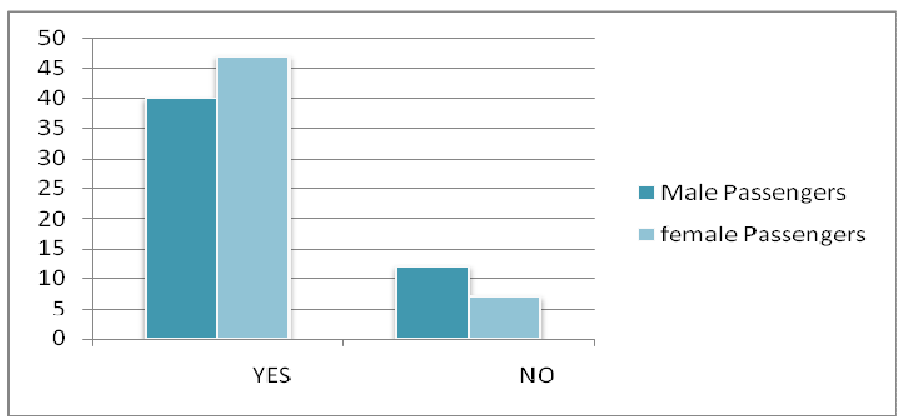

Figure 1

There is no difference of opinion between the categories of respondents (both male or female passengers agreed) regarding the statement that even after its corporate restructuring, the passenger service quality in IA is still not satisfactory, as compared to private airlines operating in India (shown in table 3 in annexure) 
H2: THERE IS NO ASSOCIATION BETWEEN THE PERCEPTION OF THE YOUNG, MIDDLE AGED AND AGED PASSENGERS REGARDING THE STATEMENT THAT EVEN AFTER ITS CORPORATE RESTRUCTURING THE PASSENGER SERVICE QUALITY IN IA IS STILL NOT SATISFACTORY AS COMPARED TO PRIVATE AIRLINES OPERATING IN INDIA

Table 4

\begin{tabular}{|l|c|c|c|}
\hline TYPE OF RESPONDENT & TOTAL NUMBER & YES & NO \\
\hline Young Customers $(<25)$ & 46 & 41 & 5 \\
\hline Age Group 25-40 & 44 & 35 & 9 \\
\hline Age Group 40-60 & 36 & 16 & 20 \\
\hline
\end{tabular}

Using STASTICAL CALCULATOR, it is found that

$\begin{array}{ll}\text { Chi-square statistic } & =21.930 \\ \text { Degree of freedom } & =1 \\ \text { Probability of chance (p-value) } & =0.0000 \\ \text { Here p-value }<\alpha & (\alpha=0.05)\end{array}$

Therefore, we reject the hypothesis

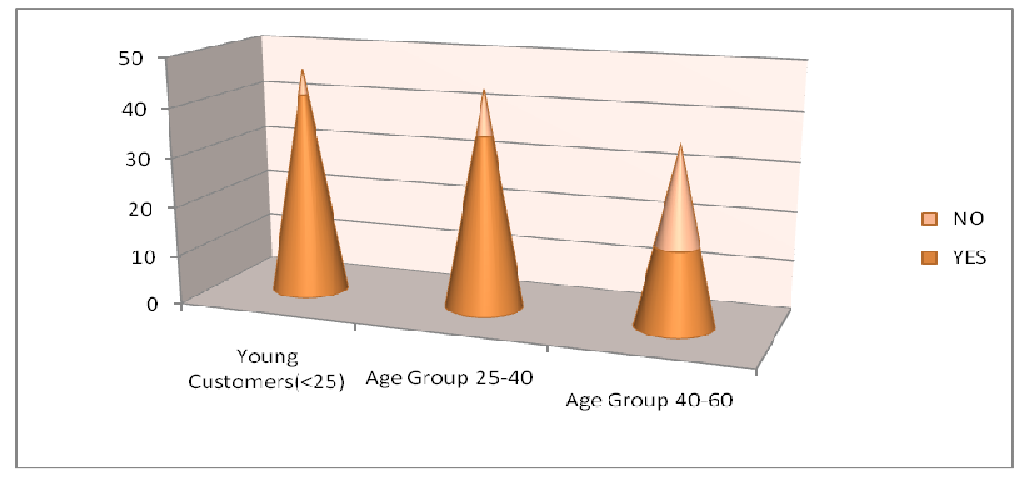

Figure 2

The perception differs from the young and aged passengers regarding the statement that even after its corporate restructuring the passenger service quality in IA is still not satisfactory as compared to private airlines operating in India (shown in table 5 in annexure)

H3: THERE IS NO DIFFERENCE OF OPINION BETWEEN THE CATEGORY OF RESPONDENTS (POSTGRADUATE, GRADUATE OR UNDERGRADUATE PASSENGERS) REGARDING THE STATEMENT THAT THE PASSENGER SERVICE QUALITY IN INDIAN AIRLINES HAS BEEN IMPROVED AFTER ITS MERGER

Table 5

\begin{tabular}{|l|c|c|c|}
\hline TYPE OF RESPONDENT & TOTAL NUMBER & YES & NO \\
\hline Postgraduate Passengers & 31 & 20 & 11 \\
\hline Graduate Passengers & 40 & 31 & 9 \\
\hline Undergraduate Passengers & 35 & 30 & 5 \\
\hline
\end{tabular}

Using STASTICAL CALCULATOR, it is found that

$\begin{array}{ll}\text { Chi-square statistic } & =4.141 \\ \text { Degree of freedom } & \end{array}$

Degree of freedom $\quad=2$ 

Airlines before and After Corporate Restructuring

$$
\begin{array}{lr}
\text { Probability of chance (p-value) } & =0.1261 \\
\text { Here } p \text {-value }>\alpha & (\alpha=0.05)
\end{array}
$$

Therefore we accept the hypothesis

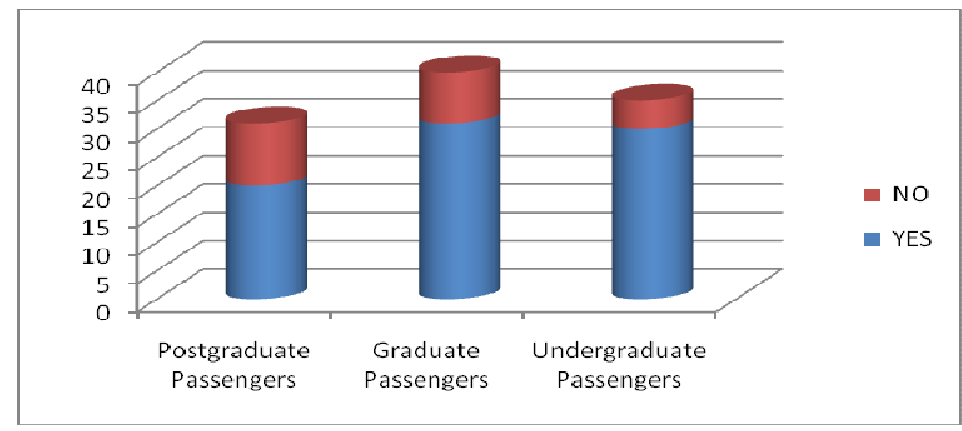

Figure 3

There is no difference of opinion between the categories of respondents (Postgraduate, Graduate or Undergraduate Passengers, all disagreed) regarding the statement that even after its corporate restructuring, the passenger service quality in IA is still not satisfactory, as compared to private airlines operating in India (shown in table 6 in annexure)

H4: THERE IS NO DIFFERENCE OF OPINION AMONG THE ECONOMY AND BUSINESS CLASS PASSENGERS REGARDING THE STATEMENT THAT EVEN AFTER ITS CORPORATE RESTRUCTURING THE PASSENGER SERVICE QUALITY IN IA IS STILL NOT SATISFACTORY AS COMPARED TO PRIVATE AIRLINES OPERATING IN INDIA

Table 6

\begin{tabular}{|l|c|c|c|}
\hline TYPE OF RESPONDENT & TOTAL NUMBER & YES & NO \\
\hline Economy class & 63 & 57 & 6 \\
\hline Business class & 43 & 32 & 11 \\
\hline
\end{tabular}

Using STASTICAL CALCULATOR, it is found that

$$
\begin{array}{ll}
\text { Chi-square statistic } & =4.894 \\
\text { Degree of freedom } & =1 \\
\text { Probability of chance (p-value) } & =0.0270
\end{array}
$$

Here $\mathrm{p}$-value $<\alpha \quad(\alpha=0.05)$

Therefore, we reject the hypothesis 


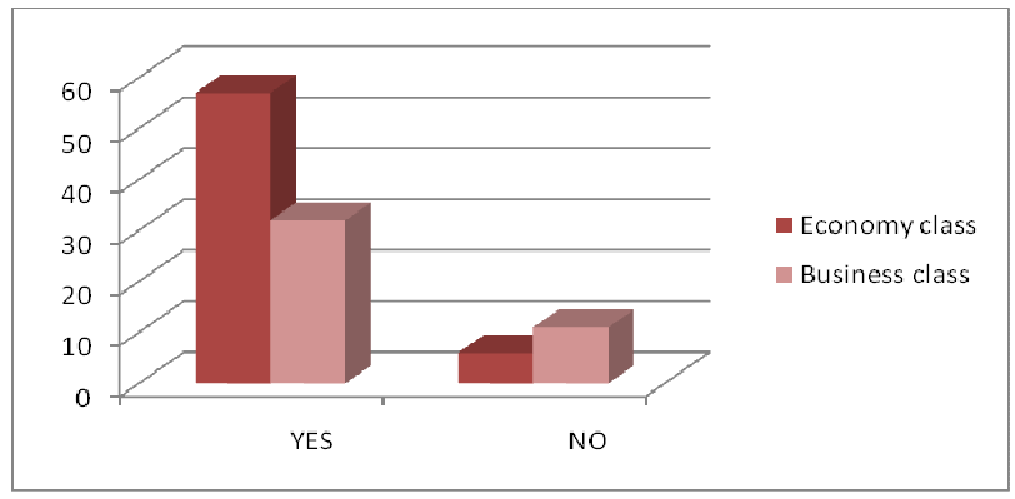

Figure 4

There is difference of opinion between the Economy class and Business class passengers regarding the statement that even after its corporate restructuring, the passenger service quality in IA is still not satisfactory, as compared to private airlines operating in India (shown in table 4 in annexure)

\section{BAYESIAN PROBABILISTIC NETWORK: HUGIN LITE OUTPUT}

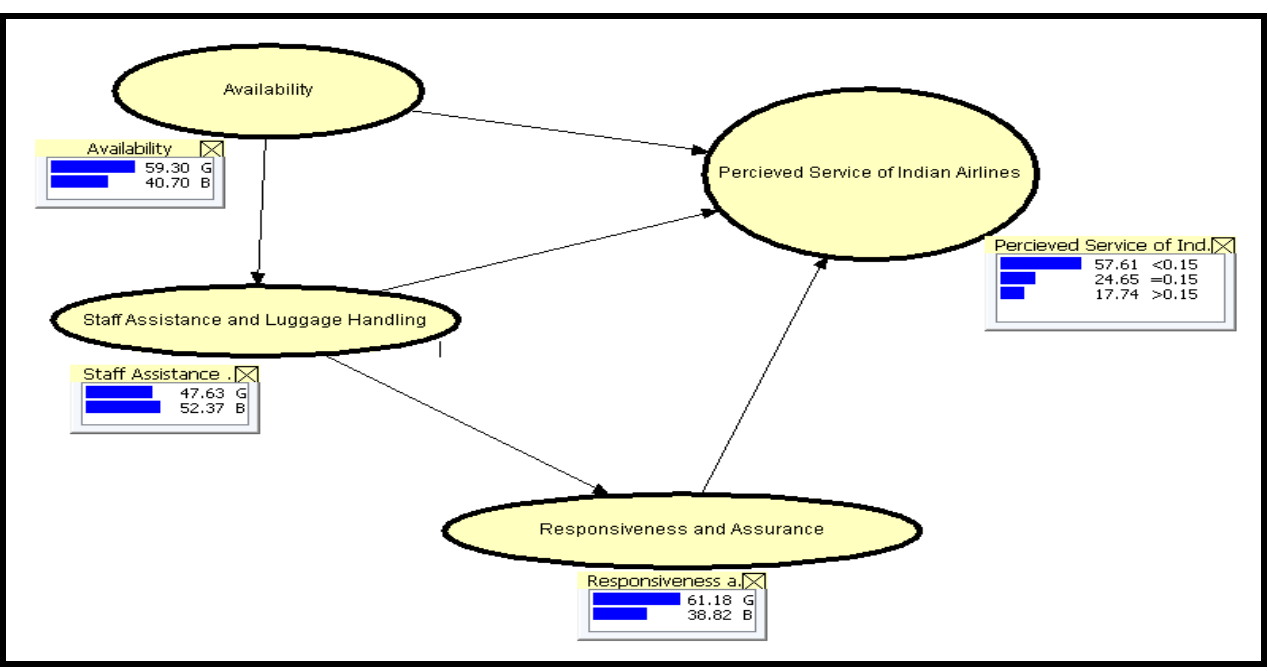

Figure 5

\section{SCENARIO ANALYSIS 1:}

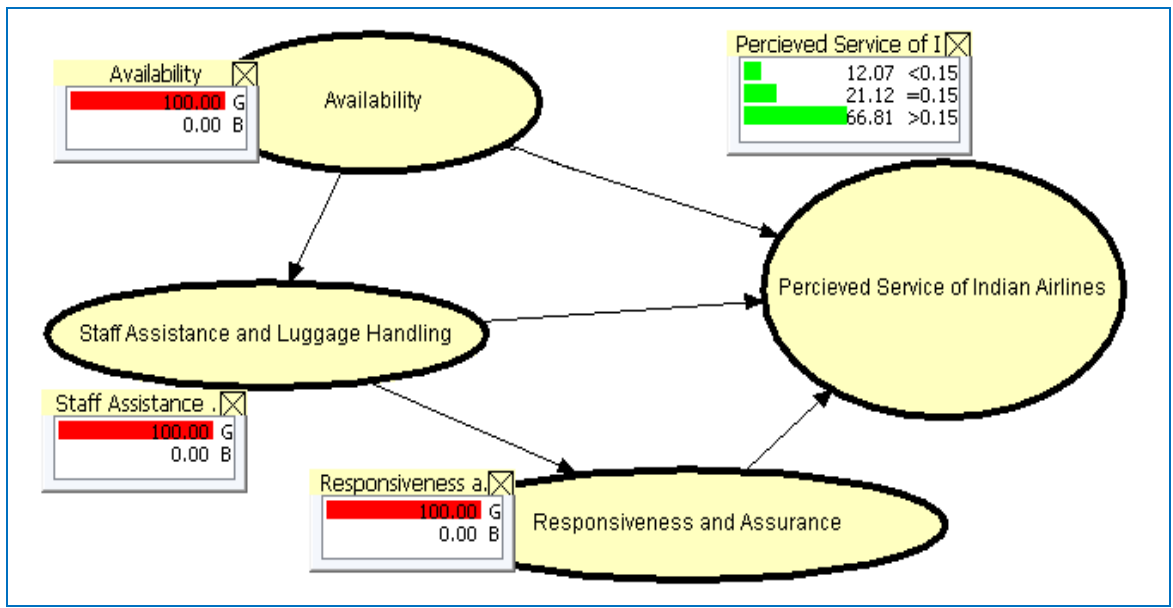

Figure 6 


\section{SCENARIO ANALYSIS 2:}

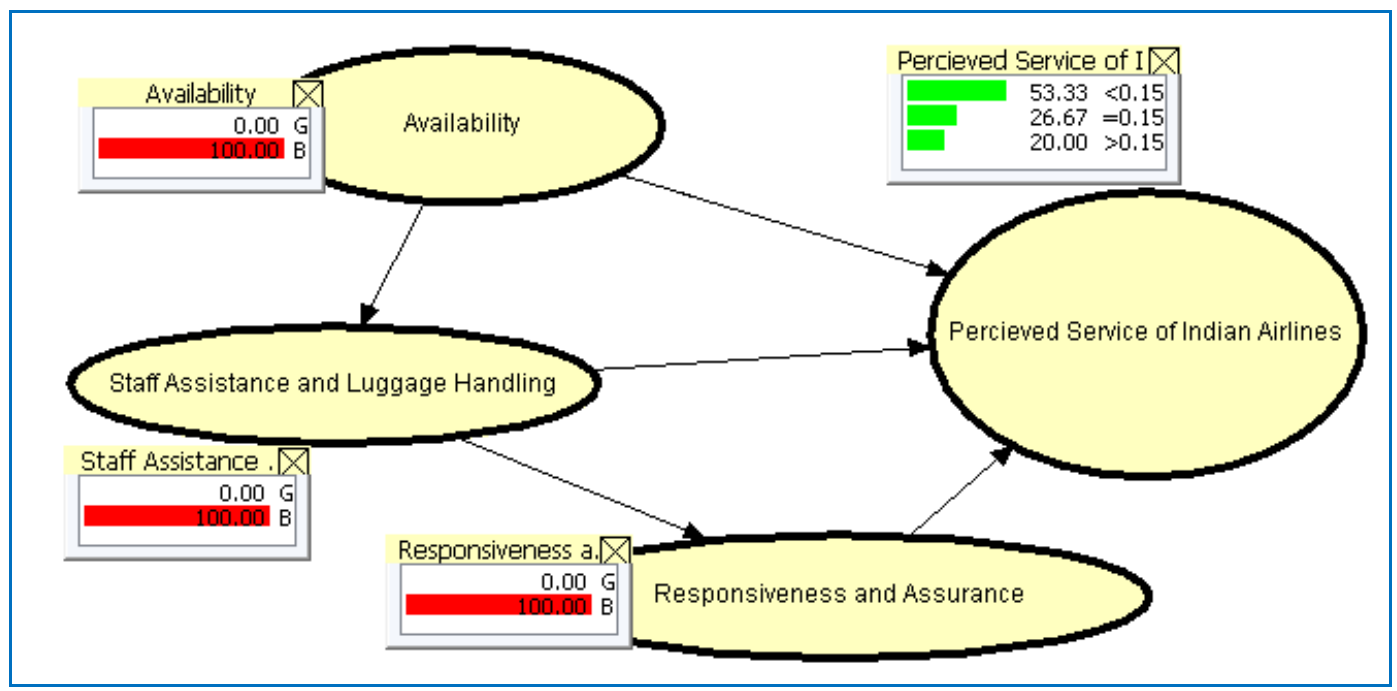

Figure 7

\section{CAUSAL ANALYSIS 1:}
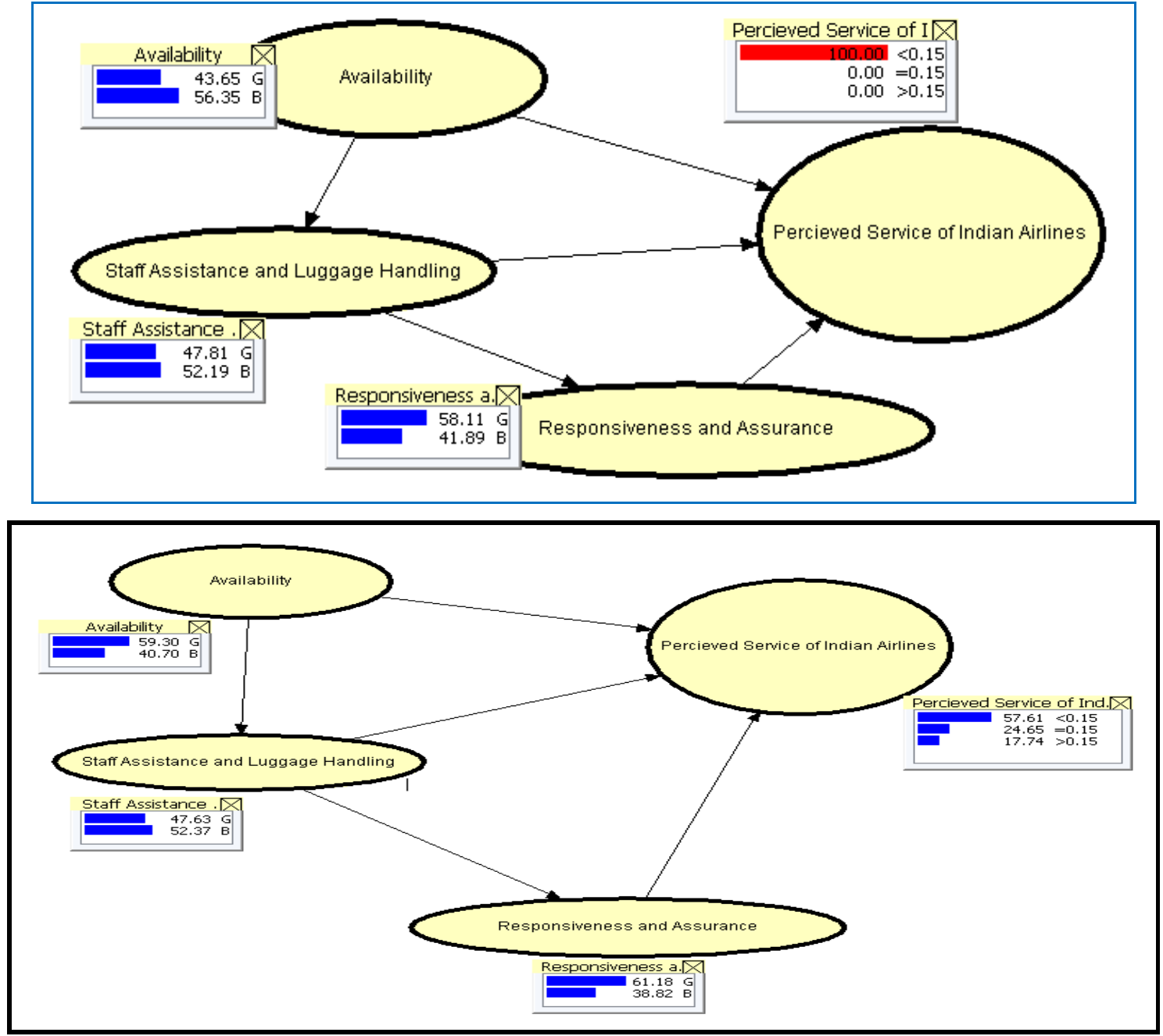

Figure 8 
CAUSAL ANALYSIS 2:
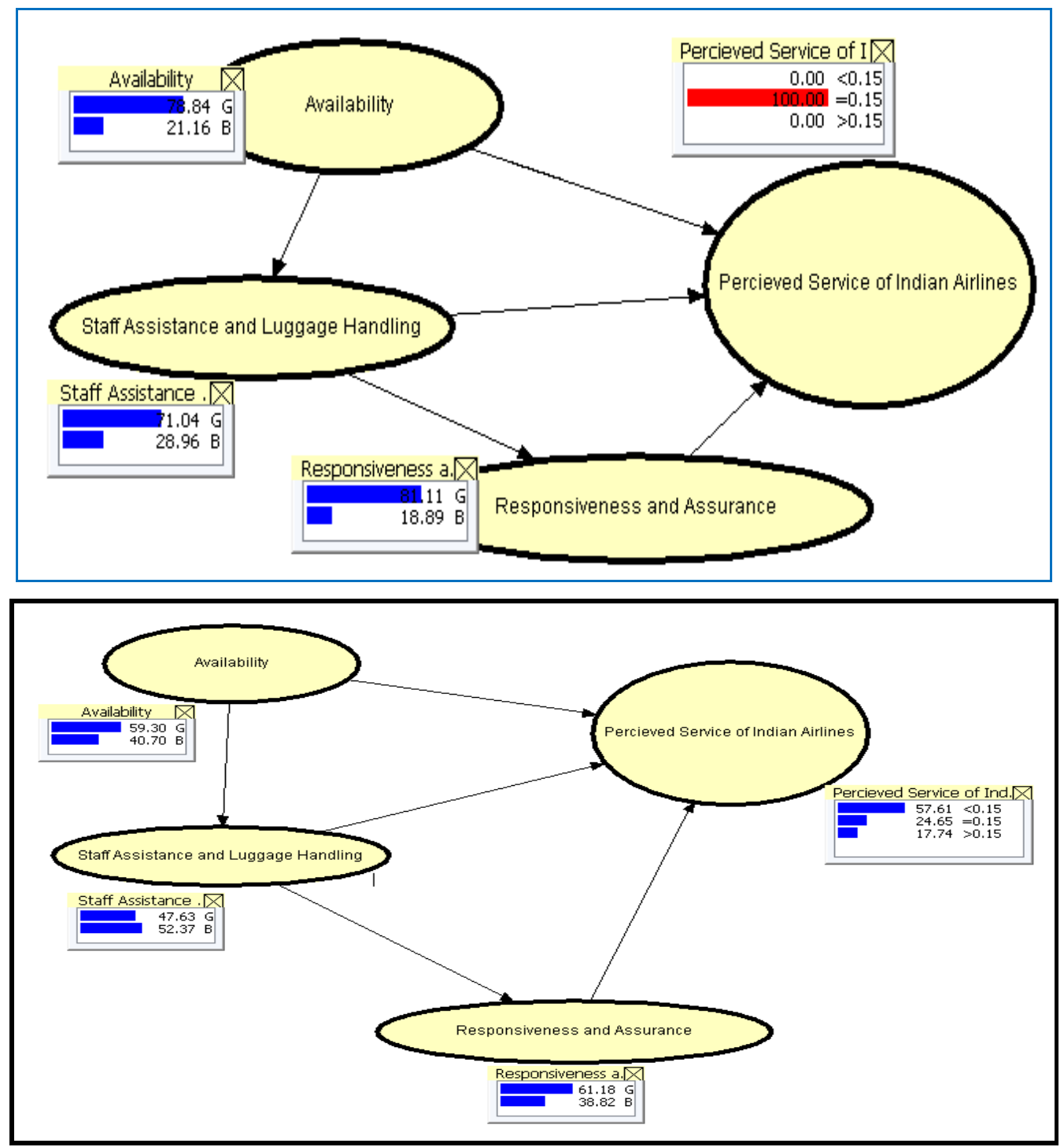

Figure 9

CAUSAL ANALYSIS 3:

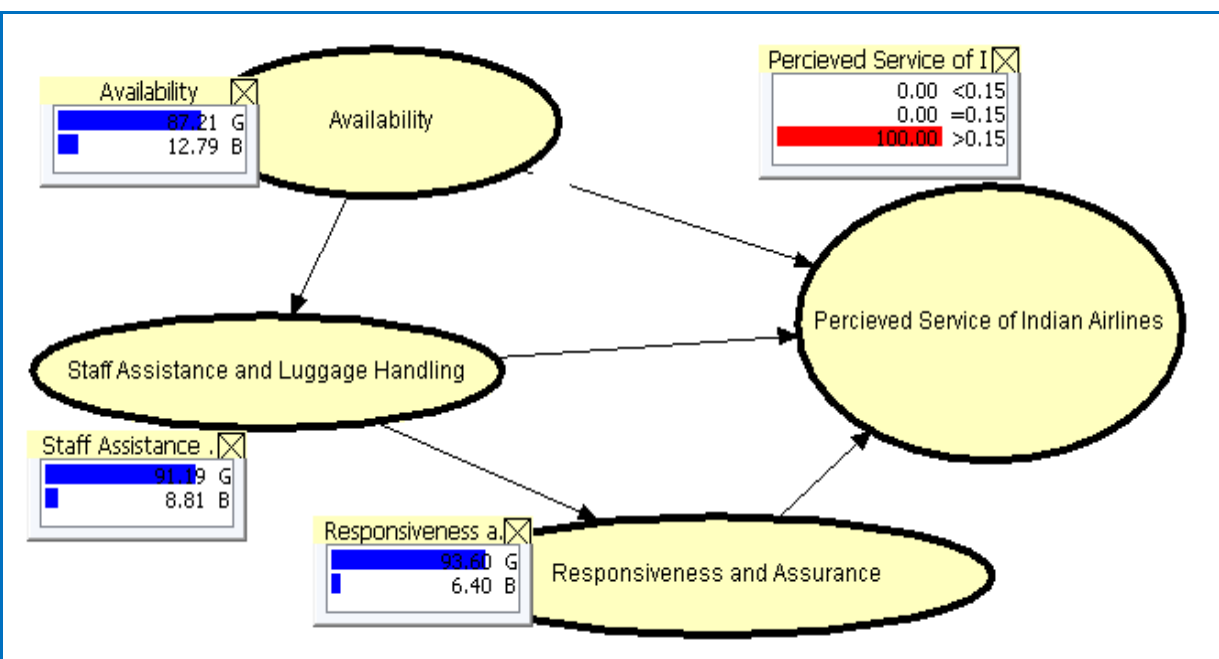




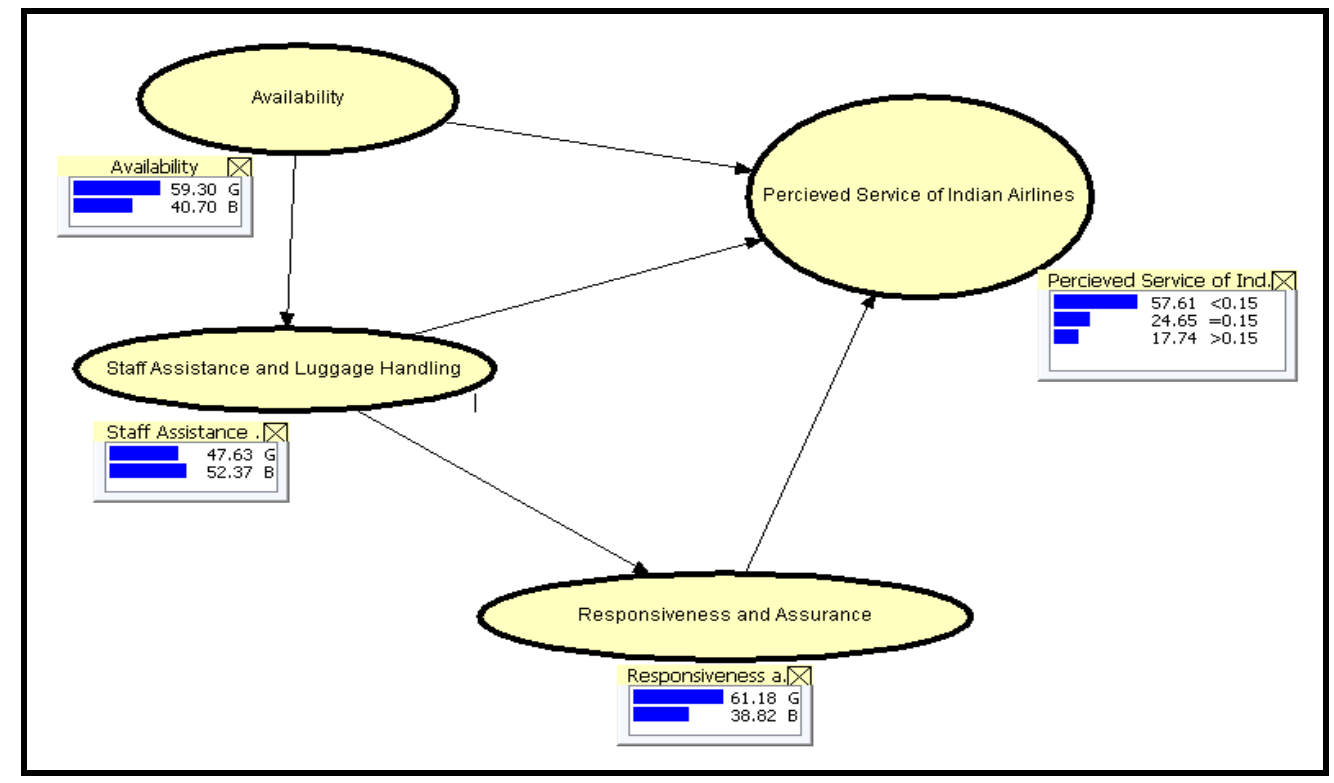

Figure 10

\section{SCENARIO AND CAUSAL ANALYSIS}

Scenario Analysis and Causal Analysis would help to analyse and make policy intervention.

Scenario Analysis: If, for example, 100 percent Availability, Luggage Handling \& Staff Assistance and Responsiveness \& Assurance are there, it shows changes in other variable, which capture the simultaneity. This is just a framework of Perceived Service of Indian Airlines.

Causal Analysis: Causal analysis is evidence based. It reverses the whole thing.

Actual values or evidence of information on Perceived Service of Indian Airlines data is propagated to all the nodes in the network i.e. used to calculate updated probabilities of all the causal factors, and as such gives us information on likely values of these causal opinion/perception variables, that may generate desired Perceived Service of Indian Airlines. This helps in strategic management of passenger growth, service quality, sales turnover/ market share and similar variables of interest.

\section{FINDINGS AND CONCLUSIONS}

After analysing the pre-merger data on the basis of the eleven problem areas, five major areas have been identified. As per factor analysis, Reliability of service in terms of safe and secure journey and in terms of providing healthy and hygienic food to their passengers is rated as the most fragile area in Indian Airlines before merger. In that very list, the next feeble area is Staff Assistance at the airport, before or after the arrival or the departure of the flight towards their passengers. Third and one of the major problems is the Responsiveness of the IA staff in general and specially in complaint handling. The next problem is the regularity and availability of the flight, which needs to be taken care of by the management to improve the image of this age-old organisation. The least rated problem area is Luggage Handling, a small percentage of the passengers have rated this as a major problem.

Now, the question arises as to whether there is any improvement after the merger, and whether it is at par with its private counterparts, with respect to passenger service quality. As per factor analysis results, Availability is found to be the most problematic area in public Airlines, followed by Luggage Handling, Staff Assistance, Responsiveness, Assurance and 
Cleanliness. Again, while data collected from the passengers of private airlines to determine the most significant factors in private airlines, factor analysis indicates Sensitivity as the most important factor to be considered, followed by Reliability, Responsiveness, Responsiveness, Easy Ticketing and Catering Service.

The chi-square test shows that, irrespective of gender, age group, educational background and class there is no difference of opinion among the passengers regarding the statement that even after its corporate restructuring, the passenger service quality in IA is still not satisfactory, as compared to private airlines operating in India

Scenario Analysis develops a Bayesian Probability Network to model, on the causal variables extracted from the first phase, whereas Causal Analysis calculates updated probabilities of all the causal factors and as such gives us information on likely values of these causal opinion/perception variables that may generate desired Perceived Service of Indian Airlines. The causal variables have, definitely, taken on values, which has resulted in good Availability, good Handling \& good Staff Assistance and Responsiveness \& Assurance.

Hence, this study reveals that this state owned public organisation is still suffering from the technical problem like Availability of flight i.e. punctuality of the flights and easy availability of tickets followed by some human factors such as Luggage Handling, Staff Assistance, Responsiveness and Assurance. It also needs to focus on the tangible aspects like cleanliness of the aircrafts. It has not yet achieved the desired state of performance to retain their existing position or to regain their previous status. So, in such a competitive environment, when all other players are trying to attract the passengers with lucrative offerings, this age old airlines is still struggling mostly with some Behavioral and attitudinal problems, and if such a situation continues in the near future, their existence may be at stake. So, it is high time to make management and employees aware and make their service more passenger-oriented.

The model combines appropriate independent or causal variables to investigate dependent service quality dimensions. It can also be utilized to construct policy interventions for a likely redressal of the situation. This means, if the marketer wants high Perceived Service of Indian Airlines, then it must be ensured that the causal variables take on appropriate values or on the contrary, if the marketer wants low or medium Perceived Service of Indian Airlines, then it must be ensured that the causal variables take on similarly appropriate values.

Thus, this research lays the foundation for future investigation on corporate restructuring, in any industry in an evolving world economy.

\section{REFERENCES}

1. Bailey, G. and Szerdy, J., "Is There Life after Downsizing"? Journal of Business Strategy, Jan-Feb, 1988, pp. 8-11.

2. Bartol, K., Martin, D., Tein, M., and Matthews, G., Management: A Pacific Rim Focus, 3rd ed., The McGraw-Hill Companies, Inc., Sydney, 2001.

3. Bolman, L.G, and Deal, T.E., Reframing Organizations Artist Choice and Leadership, 2nd, ed., Jossey-Bass Publishers, Sam Francisco, 1997.

4. Colombo, Massimo G. \& Delmastro, Marco, 2002. "How effective are technology incubators?: Evidence from Italy," Research Policy, Elsevier, vol. 31(7), pages 1103-1122, September.

5. Freeman, S.J. and Cameron, K.S., "Organizational Downsizing: A convergence and Reorientation Framework", Organization Science Feb., 1993, 10-29.

6. McKinley, W. and Scherer, A.G., "Some Unanticipated Consequences of Organizational Restructuring", The Academy of Management Review, Vol. 25 (94), 2000, 735-752. 
7. Miller, D. and Friesen, P.H., Organizations: A Quantum View. Prentice-Hall, NJ, 1984.

8. Miller, M.P., Covin, J.G., and Heeley, M.B., "The Relationship between Environmental Dynamism and Small Firm Structure, Strategy, and Performance", Journal of Marketing Theory and Practice, Vol. 8 (2), 2000, 63-74.

9. *Mitra Dipa, Service Quality Rendered By Public Bus Transport In West Bengal: A Perception Study On Passenger Satisfaction, published in International Journal of Sales \&Marketing Management (IJSMM), ISSN(P): 2319-4898; ISSN(E): 2319-4901,Vol. 6, Issue 2, Feb - Mar 2017; 1-20 (C) IASET, Achieved Best Paper Award for the quality, originality, significance in modeling and technical flow of the paper.

10. *Mitra Dipa, Personality Traits And Performance: A Perception Study in Respect of Faculty in Academic Disciplines, published in The international Journal of Indian Psychology(ISBN: 978-1-365-68609-2)Volume 4, Issue 2, No. 89, JanuaryMarch, 2017

11. *Mitra Dipa, A Study On Indian Railways: A Passenger Service Quality Audit, published in AE International Journal of Multidisciplinary Research, Archers and Elevators Publishing House, - Vol 5 - Issue 02 -ISSN - 2348 - 6724, February 2017

12. *Mitra Dipa, A Retail Audit On Customer Loyalty, South Asian Academic Research Journal-ACADEMICIA: An International Multidisciplinary Research Journal (ISSN:2249-7137), Vol. 7 Issue 2, February 2017

13. *Mitra Dipa et al,,Dynamic Fare Pricing - An application for Public Transport In Kolkata, published Vol 10 No lissue of Advances In Management,_World Research Journal, 2017

14. *Mitra Dipa, "Assessment of Vulnerability Due to Climate Change on Rural Livelihood in a Small Village of Sundarban" presented jointly with M. Ganguly at $6^{\text {th }}$ international conference at IISWBM, January, 2016 published at Survey, A journal of Management and Welfare Studies, Volume 56, 2016

15. *Mitra Dipa, A Perception Study Of Passenger Growth In Indian Aviation: An Application Of Bayesian Probabilistic Network" presented in International Journal of Arts and Sciences conference at the Harvard University Campus, 2015

16. *Mitra Dipa, "Developing A Possible Operational Risk Measure For Banking Activities: An Application of Bayesian Probabilistic Network" presented at14th FRAP conference held in September, 2014, University of Oxford, UK and published in ACRN Oxford Journal of Finance and Risk Perspectives, December,2014

17. *Mitra Dipa, January 2011a, A Study on Indian Railways With Special Reference To Passenger Service Quality, $3^{\text {th }}$ International Conference On Quality,2011[ NIQR conference issue-Expanding The Reach Of Quality], NIQR. Bangalore [has been selected as the best paper by NIQR]

18. *Mitra Dipa, November 2010d, A Comparative Study between Indian Public and Private (Low Cost) Airlines with Special Reference to Their Passenger Service, selected for presentation in Annual London Business Research Conference at Imperial College, London, published in International Review of Business Research Papers Volume 6. Number 6, December 2010 Pg.48 $-65$

19. Moers, L., "Determinants of Enterprise Restructuring in Transition: Description of A Survey in Russian Industry", PostCommunist Economies, Vol. 12 (3), 2000, 307-335.

20. Smallwood, W.N. and Jacobsen, E., "Is There Life after Downsizing"? Personnel, Dec., 1987, 42-46.

21. Selden and Colvin 2003, M\&A Needn't Be a Loser's Game, Harvard Business Review 
